\title{
ARE THERE SEX PREFERENCES IN BRAZIL?
}

\section{Raquel Zanatta Coutinho}

(i) http://orcid.org/0000-0002-2841-1480

Universidade Federal de Minas Gerais (UFMG), Departamento de Demografia e Centro de Desenvolvimento e Planejamento Regional (Cedeplar), Belo Horizonte - MG, Brasil. E-mail: quelzanatta@gmail.com

DOI: $10.1590 / 3410110 / 2019$

\section{Introduction}

On a global scale, when one thinks about sex preferences, the first thing that comes to mind is the odd sex ratio that some countries are facing in recent decades due to the widespread practice of sex selection. While in the neonatal period the mortality of boys is usually higher everywhere in the world, in countries with son preference and sex selection, the girls' mortality surpasses the boys' mortality in the post-neonatal period and remains higher during and after the first year of life, showing that social causes are affecting girls' survival. Discrimination is shown by differences in breastfeeding, food allocation (quality and quantity), proper clothing, parental surveil-

\footnotetext{
* A autora agradece o suporte do Edital 11/2017
} ADRC/UFMG.

Artigo recebido em: 28/05/2018

Aprovado em: 15/04/2019 lance, and access to health facilities and immunization (Guilmoto, 2012, p 24). Discrimination is also reflected in lower rates of school attendance rates for girls. Sonless mothers tend to use contraceptives less often and have shorter birth intervals, causing their daughters to have more siblings and bigger families, making resources even scarcer (Brockmann, 1999). In some countries in South Asia, the number of "missing girls" is reported to be close to $10 \%$.

Around the world, preferences for having a child of a certain sex, or a set of children with a particular sex composition, have always existed due to economic, religious, social and psychological reasons. But since fertility rates were high, parents were likely to achieve the commonly desired compositions. Furthermore, in the absence of prenatal sex selection, sex ratios at birth remain at normal levels (around 1.05) even if couples have additional children to achieve a sex preference (Arnold, 1997; Gupta \& Bhat, 1997; Park \& Cho, 1995). 
When Total Fertility Rates (TFR) declined in the world, mostly as a result of smaller desired family size and higher contraceptive use, many women were unable to achieve their desired sex composition. In the most notorious example in the literature, Asian women feared to be sonless and experienced strong pressures to reduce their number of daughters (Das Gupta et al., 2002). Initially, this pressure increased post-natal sex selection such as female discrimination, neglect and infanticide so that mothers could concentrate resources on sons (Park \& Cho, 1995; Bongaarts, 2013). Later, in some localities, technology fostered prenatal sex selection through selective abortion, evidenced by high sex ratios for low birth orders (Park \& Cho, 1995; Bongaarts, 2013).

In Latin America, the subject has not been studied in depth because it is believed to be irrelevant. In Brazil, any form of disclosed child neglect or violence based on sex is condemned. Abortion is legally restricted to a few situations, such as rape or risk of death for the mother. Otherwise, it brings penal sanctions for women and health care providers.

Although sex selection might not exist in Latin America, sex preferences, which are the underlying sociological explanation for sex selection, remain unnoticed in the literature. Sex preference, however, may be one of the factors responsible for leading to the birth of an additional child, since, in the absence of prenatal or postnatal sex selection practices, women who are unsatisfied with the sex composition of their families may progress to further births, increasing fertility as women and couples pursue a desired sex composition.

In Brazil, the TFR was 1.8 in 2006 and, according to estimates, it could be $5 \%$ lower in the absence of sex preferences (Coutinho, 2016). These results indicate that, although women are not selecting their first child based on sex, some might be continuing childbearing based on previous sex composition.

To my knowledge, for more than 20 years, only four articles with a demographic focus (Arnold, 1992; Souza, Rios Neto \& Queiroz, 2011; Carvalho, 2014; Coutinho \& Golgher, 2018) touched on this topic in Brazil, and only the first focused on sex preferences. Based on parity progression rates and in-depth interviews, these studies suggest that there is a national predilection for a mixed-sex family composition in Brazil. In fact, the preference for the dyad boy-girl or girl-boy is so typical that Brazilian demographers might have ignored the importance of that preference for fertility, believing that only a radical preference for one sex deserves an explanation. It is important to keep in mind that even the desire for a balanced composition may substantially increase fertility, preventing it from falling even further from replacement. Therefore, this is a phenomenon that deserves to be explored from a sociological perspective by stratifying the analyses by social groups and visualizing which social norms may be behind family composition.

Demographic and Health Surveys offer a unique opportunity to understand sex preferences because the surveys go beyond parity progression rates and include questions about the size and composition of women's ideal families. In this article, I will first describe some of the seminal studies regarding sex preferences, and then I will formulate a hypothesis for the Brazilian case. To avoid ex-post rationalization, I will only analyze the ideal sex composition of women who have never had children but who intend to do so. A comparative analysis will explore differences by levels of wealth, education, race, region, urban/rural residence, religion, church attendance, marital status and work status to understand how social structure has been shaping sex preferences.

\section{Mechanisms and explanations for sex preferences}

There are economic, religious, social and psychological reasons to have a son or a daughter (Guilmoto, 2012; Johnson-Hanks et al., 2011). These different motivations arise because society ascribes different roles and expectations to people based on their sex, which is defined as a "gender system". When gender roles, costs and benefits are different, sons and daughters are not substitutable (Pollard and Morgan, 2002). Preference may or may not be enacted through prenatal or post-natal practices. Historically, preference for males has been more common, given the predominance of patriarchal societies. 
The driver of son preference is the male role in the family and the lower value of women in society (Guilmoto, 2012; Wood \& Bean, 1977; Das Gupta et al., 2002). In traditional societies, men are considered to be more suitable for agricultural work and can acquire better-paid labor force positions. Men are also necessary to perform religious ceremonies in some ethnic and religious traditions and provide continuity of the family name in patrilineal households (Das Gupta et al., 2002; Park $\&$ Cho, 1995). Further, sons are a primitive form of social security, responsible for supporting parents in old age (Wood \& Bean, 1977). As a result, women socialized into these societies follow these common norms about gender roles that will shape their preferences for offspring.

In places where family sizes are more flexible, having at least one girl is useful for company and household work. In a very psychological piece of work, Teichman, Rabinovitz and Rabinovitz (1992) suggest that women prefer daughters because they could be the caregivers for their parents in old age, but also because mothers can work out their own identify conflicts through their daughters. In some societies, however, daughters are potential brides with a large cost for parents. Besides the fact that their parents must pay their dowry, they are not supposed to contribute to their parents' house or even see them after marriage; they are expected to leave their homes of origin to open space for their sisters-in-law, and they are also deprived of inheritance and expected to work for the husband's family (Das Gupta et al., 2002).

Dyson and Moore (1983) show how gender differences in treatment can lead to differential mortality in India. Indicators of sex discrimination are higher in the northern states compared to the southern states, which also have lower fertility, lower infant and child mortality, and later age at marriage. These regional variations are a reflection of sociocultural schemas regarding family and kinship structure. In the south, women are allowed to inherit property, marry at later ages, and have more freedom picking their husbands and occupations. Besides that, the costs of the wedding are shared between brides and grooms, women can maintain contact with their kin, daughters can help their old parents, and religious rituals are shared ${ }^{1}$. The northern states are characterized by the dowry system, monitoring of women's behavior, and weak emotional ties between husbands and wives.

Other countries have gone through important cultural changes to accommodate daughters. The Family Law of 1989 in South Korea, for example, established that women could be allowed to inherit property, contribute to their parents' households, and get custody of their kids (Chung and Das Gupta, 2007). The Korean government has also encouraged women to work and remain employed after marriage.

In more developed societies, where the welfare state has taken over some responsibilities regarding care and pensions for the elderly or disabled, children might no longer be an expected source of economic security or care when the parents reach old age. In those localities, preference for males is less tangible and important. A report (Arnold, 1997) and an article (Bongaarts, 2013) show statistics on the status of discrimination in different countries. Daughter preference is more common in Europe and in the Americas, where girls' prestige seems to be better. Modernization "undermines religious commitment, weakens male privileges, and enhances the status of women, thus eliminating the factors usually invoked to explain the son preference of traditional societies" (Brockmann, 1999, p. 3). Preferences for women are then linked to women's increasing status and changed gender role (Teichman, Rabinovitz \& Rabinovitz, 1992).

Hank and Kohler (2000) also find a preference for girls in the United States, Vietnam and Israel. As described in the international literature, boys suffer more threats during their lives, especially in a society exposed to wars and hostilities. For this reason, having girls could be a way of preventing the loss of children (Jacobsen, Moller \& Engholm, 1999). Gender preferences are "embedded in cultural and religious traditions and community norms shaping individual attitudes and behavior" (Hank \& Kohler, 2000, pg.4).

There is growing evidence that a preference for balance, found in Latin America and Africa (Arnold, 1997) and in Europe (Hank \& Kohler, 2000) has recently been giving way to "gender in- 
difference" (Pollard \& Morgan, 2002). The declining effect of the sex composition of the first pair of children on the third birth is consistent with a convergence in gender roles and norms for parents and between children: daughters and sons are increasingly likely to be given the same educational and professional opportunities, and also to have access to the same types of activities. Thus, gender indifference reflects a shift in society toward gender neutrality in legal and administrative regulations as well as in work and family roles (Bianchi, 2000, in Pollard \& Morgan, 2002, p. 603). According to the authors, the more rigid a gender system is, the more important the achievement of specific gender compositions will be, even if the preferred composition is one child of each sex. In societies such as France that have great gender equity, the percentage of people without a preference (e.g. stating that the sex does not matter) is high (Marleau \& Maheu, 1998).

One recent piece of evidence disputes this finding, however (Miranda, Dahlberg \& Andersson, 2018). In Sweden, the third most gender-equal country in the world (World Economic Forum, 2018), beginning in the 80 s, a noticeable preference for daughters became more evident, which makes the authors presume that girls and boys continue to have different traits and benefits even if gender roles are more flexible. Using birth history data, they find that mothers of only one boy have higher $(+4 \%)$ second birth rates than mothers of only one girl, and mothers of two boys have higher third-birth rates than mother of two girls $(5.5 \%$ higher). Besides, when the first child was a girl, women showed less preference about the sex of the second child (74\% said it would not matter) than when the first was a boy (57.7\%). Preference for a female as a subsequent child was also higher if the first child/children were male when compared to the preference for a boy as a subsequent child if the first child/children were female. The authors also used data on perceived social pressure to confirm the finding that social schemas permeate the decision to have children. Couples with two sons report being 3.5 times more likely to feel social pressure for a third birth than parents of two daughters (Miranda, Dahlberg \& Andersson, 2018).
Contrary to the arguments presented by Pollard and Morgan (2002), that increasing equality may cause gender indifference, Miranda, Dahlberg and Andersson (2018) hypothesize that increasing gender equality in a society may, in fact, increase the advantages of having a daughter rather than a son. Daughters' double advantage comes from the fact that they are now able to contribute to the economic wellbeing of the household, as men have done in the past, but they are still seen as the main source of reliable care and social support. Research in Brazil confirms that women are more likely to engage in activities of care than men (Motta, 2010). A different study in Brazil found that $50 \%$ of the caregivers of the participants (age 80 and over) were daughters, while only $4 \%$ were sons (Gonçalves, 2013).

\section{Empirical evidence and hypotheses}

When social schemas make a certain sex composition more advantageous, but life does not go as planned, the only way to achieve sex preference, in the absence of sex selection abortion and infanticide, is by continuing childbearing. Around the world, evidence from 17 countries suggests that in most European countries a couple is more likely to have three children if the first two are of the same sex (Hank $\&$ Kohler, 2000). In general, parents who have two children of the same sex have 1.3 times more chance of continuing to bear children (Waller, 2010). In one of the first studies for the North American population, Wood and Bean (1977) calculate parity progression rates and find that Mexican Americans have a higher probability of progressing to higher birth orders than Anglo Americans, but that both prefer mixed families and in both populations the probability of progressing decreases among parents who already have a mixed sex composition among their children. At lower parities, however, both populations appear indifferent to the sex of their children. According to Hank and Kohler (2003), the proportion of people who express a preference about the sex of their next child is higher among those who have already born one child, suggesting that people might be actually aiming at a balance. 
There are not many published articles on the topic in Brazil. Preferences for a mixed composition were visible when a study by Arnold (1997) using the 1986 DHS found that the percentage of currently married, non-pregnant women aged 1549 in 1986 who wanted another child was larger for the women whose children were of the same sex. While $23 \%$ of women who had a boy and a girl wanted more children, $31 \%$ of the women who had two girls or two boys wanted more children. No other work has extended Arnold's study for the more recent Brazilian data.

Souza, Rios-Neto and Queiroz (2011) found mixed preferences using national household survey data (PNAD, Pesquisa Nacional por Amostra de Domicílios) from 1990 and 2000. While 47\% of mothers with two children of different sexes would have a third birth, for those with either two girls or two boys, the percentage having a third birth would go up to $51 \%$. Although this data is more recent than that cited by Arnold (1997), the focus of their research was not on sex preference, so no further explanation was provided.

Carvalho's (2014) qualitative study examined the ideas of married upper-class couples as they considered having one extra child. The author found that couples become very happy and satisfied with the sex of their existing children even if the child was not of the sex they preferred. This work demonstrates how life's conjunctures lead to malleable fertility desires, as the Theory of Conjunctural Action suggests (Johnson-Hanks et al., 2011). On average, however, she found that women tend to prefer daughters while men tend to prefer sons, in accordance with the literature.

Coutinho and Golgher (2018), decompose Brazilian fertility rates to find how sex preferences might be responsible for increasing family size. They find that women in the low socioeconomic strata and with low education levels are most likely to proceed to higher-order births given the sex of the previous children.

Since fertility rates were higher than desired family sizes in 1986 (the Total Fertility Rate was 3.2 children per women, while Desired Family Size was of 2.79 children per woman ${ }^{2}$ ), I assume that the majority of women in Brazil were achieving their sex compositional ideals by having a large number of children. In other words, no matter how diverse their ideal family sex compositions were (e.g. one of each sex, two girls, two boys, one girl, one boy, two girls and one boy, two boys and one girl, and so on), the majority of women were achieving the amount of children of each sex that they wanted one way or another; by either having unwanted pregnancies ${ }^{3}$ or by purposely continuing childbearing until the composition was accomplished.

In 2006, however, the TFR fell below the Desired Family Size (1.87 vs. 2.1 desired children per women). Although women may still have an ideal composition in mind, smaller fertility targets keep them from continuing childbearing in order to achieve a certain number of boys and girls. Given that preferences are embedded in the social context, I expect their preference will be for mixed composition. I also expect that, with the decline in fertility rates, women will be more realistic about the possibilities of accomplishing a certain desired sex composition and will declare themselves to be more indifferent to gender.

A number of factors may interfere with goals for a certain number of children and should be taken into consideration. An important factor is the marital status. Teichman, Rabinovitz and Rabinovitz (1992) find that women, in general, prefer daughters for company, but when men's and women's preferences are considered together couples are overall more likely to prefer sons. Further, Bongaarts (2013) observed that the average desired sex ratio for single females is 1,05 boys for each girl, while for married women it is 1,23 boys for each girl as they are partially influenced by their husbands. Pollard and Morgan (2002) suggest that couples desire at least one child of each sex based on the fact that each sex will have different "trait, strengths, leisure activities and interests” (p. 602). For both man and woman, there might be a desire to watch the child grow and to interact with that child in those particular activities that are genderspecific. Because men and women generally prefer children of their own sex, especially for a first child (Jacobsen, Moller \& Engholm, 1999), the disagreement between the couple could lead to higher birth orders because they will continue childbearing in 
order to achieve a mixed composition and satisfy both parents (Marleau \& Maheu, 1998).

While Beckman (1984, in Stein, Willen \& Pavetic, 2014) says that each partner negotiates on the basis of individual intentions, von Rosenstiel et al. (1986 in Stein, Willen \& Pavetic, 2014) argue that partners have multiple influences upon one another. Power becomes more symmetrical as women gain more education and increase their labor force participation, which is also reflected in an increased preference for daughters among this subgroup. Although male partners have greater relevance in deciding whether to continue childbearing, females have veto power because they bear the physical costs of pregnancy, birth and child-rearing (Stein, Willen \& Pavetic, 2014).

Women who are single, separated, divorced or without any partnership will be more likely to prefer girls because they will lack the male factor in increasing a desire for a boy. Alternatively, raising a boy could also be considered harder without a father figure around, or it may be psychologically complicated to have a son that resembles his father, a man with whom the mother does not have a strong relationship. Currently, in Brazil, the number of young boys put up for adoption is 30\% higher than the number of girls, according to the National Registry for Adoption (CNJ, 2015). If one assumes that single mothers are more likely to put children up for adoption, it is easier to understand sex preferences as a driving factor for this differential.

Place of residence may also be the source of different sex preferences, because rural and urban areas present different social divisions of labor. While rural men were expected to perform more arduous tasks associated with the agricultural sector, rural women were expected to raise children and complement the income with "lighter" tasks such as handcrafts (Paulilo, 1987). Thus, although sons have higher productivity, daughters are necessary for the household, which might have made families opt for bigger families with mixed compositions. In urban areas, both children usually have the same social functions and are thus more substitutable.

Due to the masculinization of agricultural work, as described by Abramovay and Camarano (1998), modernization and urbanization changed the possibilities presented to the children and they started to migrate to the cities, especially daughters, who had lower remuneration compared to sons for the same rural work (Paulilo, 1987). While in agricultural and manual labor physical strength was an asset, most current jobs do not require this feature, but instead require features, such as patience and dexterity, in which females are not disadvantaged when compared to males (Blau \& Kahn, 2000). Thus, in more recent decades, urban areas witnessed an increase in the labor market participation of females, while male labor force participation was stable at best (Juhn \& Potter, 2006; Wajnman $\&$ Rios-Neto, 2000). This indicates that the labor market has been progressively turned into a female locus, with a relative increase in females' participation as workers and heads of households. Moreover, with an increase in the service sector, women gained access to better-paid occupations (Juhn \& Potter, 2006).

There are some regional historical specificity that might also matter. Until the 60s, land distribution among children in the macro-region of the South was called Minorato. This was a patriarchal schema that consisted of the last son inheriting the parental property and the responsibility of taking care of the parents in old age (Mello et al., 2003). The remaining sons were expected to acquire agricultural skills and to live on other land bought by the family. This system was possible due to the great availability of land and geographic mobility, the social pressure for young people to move away and become agricultural workers, the existence of an "agricultural dowry" (land and equipment), and the exclusion of daughters from this process.

With time, modernization changed the role of the last-born children who had previously been expected to stay on the land. Children were able to migrate to cities, and daughters began to receive the agricultural dowry. Nevertheless, daughters are still excluded from inheriting parental land, and they do not seem to participate in decisions regarding work (Mello et al., 2003).

Religious affiliation may also matter (Marleau \& Maheu, 1998; Pollard \& Morgan, 2002). Patriarchal and conservative religious institutions such as Catholicism and Pentecostalism (Gallagher, 
1996) provide couples with schemas of higher family sizes and lower contraceptive practice. They also provide them with structural functionalist views on family in which husbands and wives have complementary roles within the ideology of the separate spheres (while men are the breadwinners, women are expected to do the domestic labor, take care of the kids, take care of their social networks and of their husbands). Although women are subordinate to men, their roles are harmonizing and equally important. This could be associated with a desire to have a balance of male and female children - or even to indifference, for couples who simply intend to comply with God's plans.

Another important factor that might influence sex preferences is race. In the case of Brazil, black males aged 15 to 24 present very high homicide rates directly caused by their involvement in drug trafficking, criminality, gang violence, police brutality and racial profiling (Waiselfisz, 2013). For instance, young black male's annual homicide rate (above 27.5 per 100 thousand in all 26 Brazilian states plus the Federal District and reaching 201.1 per 100 thousand in the state of Alagoas in 2011) surpasses the mortality rate of many countries under warfare (Waiselfisz, 2013). Compared to their white counterparts, 17 states had young white male's homicide rates below 27.5. The number of missing black boys in Brazilian society cannot be ignored. Part of the underlying cause of the problem is lower socio-economic levels and negative ideological and cultural representation of black and poor individuals.

On top of poor males' increased risk of being victims of violence, women are faring better than men in regards to education completion and university graduation, both in general and among the disadvantaged strata (Wajnman \& Rios-Neto, 2000; Whinter \& Golgher, 2010). That means that having a daughter could be more advantageous, in particular, among the poor.

Moreover, preferences might be more salient for poor women, because from all the possibilities that middle-and upper-middle-class women have in life (career, marriage, children, and personal goals), childbearing is the only thing poor women can have control over (Berquó, Garcia \& Lima,
2012). Their attachment to their family compositional goals might be something they cannot give up. Waller (2010) shows how there is a higher tendency for lower-class couples to continue childbearing after having two children of the same sex.

Lastly, Hank and Kohler (2003) find that highly educated women have their own sources of income, so they do not need to rely on their sons or husbands for economic support, which increase their bargaining power. The same reasoning could be applied to women in the labor force. Nevertheless, education tends to increase egalitarian views (Lameirao, 2011), which, in turn, could relax gender expectations and preferences. Finally, achieving a balanced sex composition among her children might disturb the woman's economic productivity, making her more concerned about the number and timing of children than their sex.

\section{Data}

Data come from the Brazilian DHS of 1996 and the PNDS of 2006. These databases, which are nationally representative and cross-sectional, focus on women of reproductive age (15-49) and their birth history. Sample sizes were of 12,612 women in 1996 and 15,575 in 2006.Data were collected in the five Brazilian geographic regions and in urban and rural areas, as well as in urban slums (Ministério da Saúde, 2008). The DHS and similar surveys such as the PNDS are ideal for performing analysis of sex preference because their reproductive intentions data allow study of desired family size and composition, and because they are the only nationally representative databases offering this information. Given that these Brazilian surveys are not longitudinal and that some subsample sizes are not large, some limitations need to be addressed before proceeding with the analysis.

The first is that ex-post rationalization, which happens on retrospective surveys, attenuates the effects of sex preferences because women reconsider their preference after giving birth (Wood \& Bean, 1977 , p. 130). Research also indicates that when parents fail to achieve the desired sex balance by the time they reach the number of children intend- 
ed, they tend to revise their family goals upward (Wood \& Bean, 1977). I will avoid this limitation by focusing on a sub-sample of women who have never had children but who wish to have at least one child. If I were to analyze the preferences of those who already have started childbearing, a better indication of sex preferences would be real behavior (less influenced by normative response bias), which could be explored using parity progression rates by composition of previous children. Nevertheless, prenatal ideal sex preferences might not be translated into practice once these women start childbearing and are confronted with real sex ratios and the challenges of pursuing their initially desired sex composition at the risk of increasing their family sizes excessively.

A second limitation of this paper is the timing of covariates. For example, a woman's marital status may vary throughout her reproductive life and may not be the same as at the moment of the interview. Unfortunately, I cannot avoid this problem totally, but this should not affect data on women who have never had any children, since their reproductive intentions - their ideal family size and composition are being captured at the same time as their marital status: the time of the interview.

Other confounding aspects are caused by age and birth cohort effects: due to declining desired family sizes and declining fertility rates over time, older women and women in 1996 usually had more children than younger women and women in 2006, so they would be more likely to naturally achieve their sex composition preferences. Besides, a childless 45-year-old woman in 1996 is probably not childless for the same reasons as a 45 -year-old in 2006. Neither is a less-educated woman who is childless at age 40 , childless for the same reasons as a 40-year-old college-educated woman. To minimize this problem, I perform the analyses separately by year, by desired parity, and with controls by age.

Other important controls are absent from this analysis, such as occupation, full-time employment, number of parental siblings, and age at first birth, as well as interaction effects. I recognize that family composition and fertility intentions are a dynamic sequential decision-making process that should be modeled as such. Unfortunately, the DHS and the PNDS are not longitudinal and do not allow one to study change over time in actual living conditions, personal goals, and interactions that might happen before conception, or even during pregnancy and after birth, as suggested by Stein, Willen and Pavetic, (2014).

\section{Variables and methods}

In order to investigate ideal sex preferences of women who have not started childbearing, and to shed light on the possible influences of socio-demographic variables on reproductive intentions, a variable called Desired Family Composition (DFC) was formulated using the women's answers to two different questions.

The first question asked women about their ideal family size: "If you could choose the exact number of children to have throughout your whole life, what number would it be?" (translations are mine). Women who answered "up to God" were excluded and, since they are a small part of the sample, they will not significantly affect the results.

The second question asked women about ideal sex composition for their offspring: "How many of the desired number of children, asked in the previous question, would you like to be male, how many would you like to be female, and for how many you do not care about the sex?" (translations are mine). The answers for both questions were grouped so as to form combinations of ideal number and sex of desired children. Over 30 combinations were found for the surveys, as Box 1 shows. Women were not asked the preferred order of each sex.

For those who wanted one child, there are three options, hereby coded as one boy ("b"), one girl ("g"), or one child whose sex does not matter ("x"). For those who wanted two children, there are six possibilities: bb (two boys), bg (a boy and a girl), gg (two girls), xx (two children whose sex doesn't matter), $x b$ (one boy and one child whose sex doesn't matter), and $\mathrm{xg}$ (one girl and one child whose sex doesn't matter). In 2006, higher parities were less cited than in 1996, and the variety of compositions were also smaller.

In order to investigate what would explain the different preferences by social groups, I reclassified 


\section{Box 1 \\ Desired Family Compositions (DFC) that Were Found in the DHS 1996 and the PNDS 2006, All Women, Brazil.}

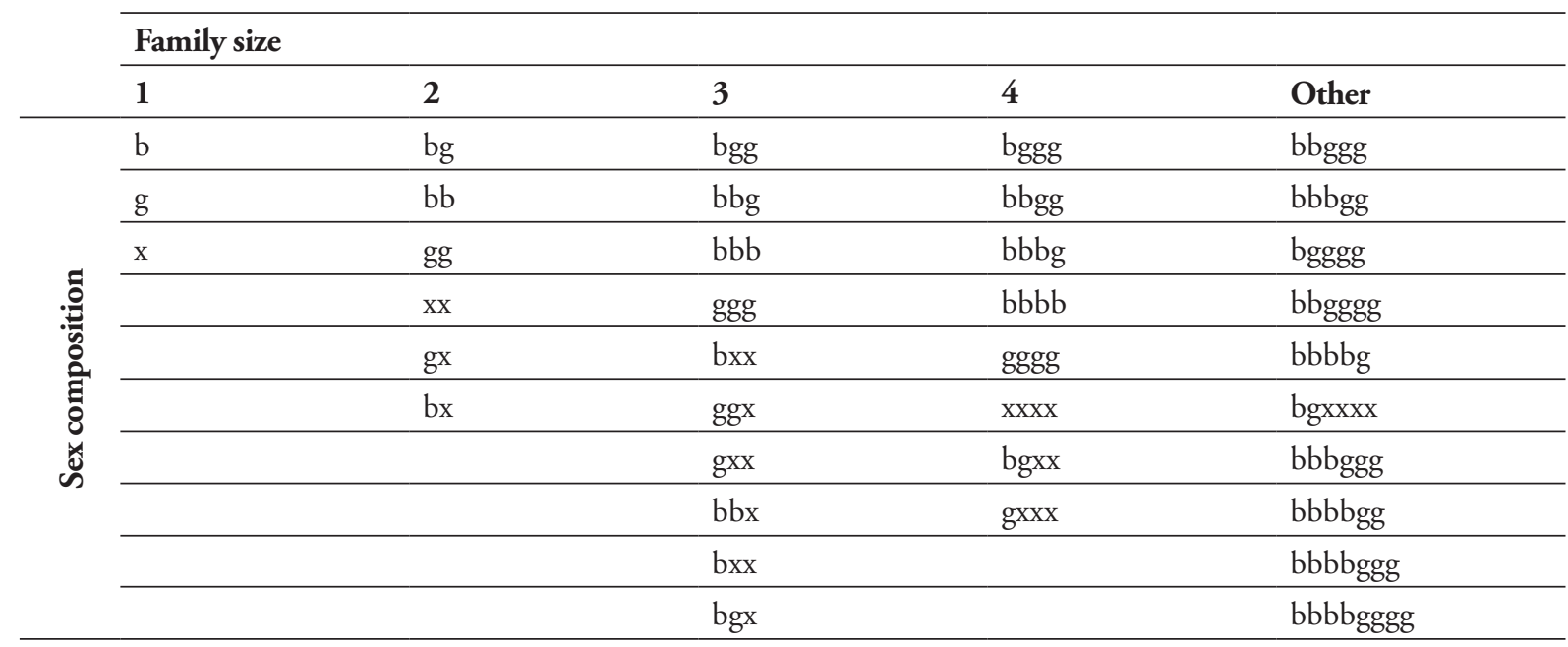

Sources: DHS 1986 (BEMFAM, 1987) and PNDS 2006 (Ministério da Saúde, 2008).

the groups in Box 1 into variables that represent the combinations of ideal composition and parity. These categories became the dependent variable in the multinomial logistic regression models throughout this paper.

The multinomial variable created using sex preferences contains four categories, which are:

- Balance - preference for balance

- Indifferent - no sex preference

- Daughter preference - preference for girls

- Son preference - preference for boys

The sample distributions into these four categories can be seen in Box 2. Notice, in Box 2, how I classified the sample into different desired family sizes, because I have reasons to believe that a woman who wishes to have only one child is different from one who wishes to have three children even if their sex preference is the same. I also did that because the objective for this analysis is to study sex preference and not ideal family size.

On Tables 2 through 4, and on Table $\mathrm{C}$ of the Supplemental Material, I use multivariate analysis to observe how ideal sex preferences behave in the presence of multiple selected covariates. Multivariate models also allow me to capture variance that cannot be captured with univariate regression (Hosmer \& Lemeshow, 2000). The selected covariates utilized in the models are as follows (reference categories with asterisk): Marital status (Married or in Union $=1^{*}$, Separated or Divorced $=2$, Single and Never married $=3$ ); virginity status (no=0, yes $=1$ ); place of residence $(0=$ urban, rural $=1)$, macro-region (North $=1$, Northeast $=2$, Southeast $=3 *$, South, $=4$, Center-West $=5)$, religious affiliation (Catholic $=1$, Protestant $=2$, No Religion $\left.=4^{*}\right)$, church attendance (no $=0$, yes $=1$ ), race (White $=1^{*}$, Black (includes Brown)=2), wealth index (continuous at the regressions and divided into 5 levels, ranging from 1 to $5,5$ being the highest quintile $)^{4}$, achieved education (continuous at the regression and divided into 5 levels, ranging from 1 to 5,5 being the highest level), and labor market participation (no=0, yes=1). Because the influence of these variables might change from year to year, I ran each regression separately by survey year.

In order to control the fact that older women were under a high fertility schedule for most of their reproductive lives, age was kept as a control. 
It has been suggested that the representativeness of the sample would be affected once I selected only women without children, and that therefore I should try to limit my sample to women age 15-25, who are very close to the beginning of their reproductive lives. A problem with that approach is that by selecting young women I would lose important variability in education levels and marital status that only appears later in life. Among the poor, age at the time of the first child's birth is much lower than 25. Thus, I opted to include women of all ages who had never borne a child, and to keep the appropriate control for age. ${ }^{5}$

\section{Results}

The most preferred sex composition in Brazil is the dyad boy-girl for almost every social category (47\% in 1996 and $41 \%$ in 2006), but the percentage of women who report this preference has declined in almost every social group. The second most preferred composition continues to be 2 children with no sex preference; this preference grew from 9 to $14 \%$ in ten years and is the second most prevalent in most social categories. The third and fourth most preferred compositions in 2006 are to have one child of any sex or one daughter (8\% and $6.15 \%)$. If women who do not wish to have children were included in the analysis, this preference would be among the top 4: preferences for zero children slightly increased from 6 to $7 \%$. It was much more common to find compositions of four children, and to find more diversity in compositions, in 1996. These distributions are available in the Supplemental Material, Table A.

The proportion of women who mention balance (bg) as their preferred composition has declined from 1996 to 2006, while the proportion of women who are indifferent to the sex of their children (xx) has increased (See Supplemental Material, Table B). I performed Chi Square tests to check whether these differences in proportions are significantly different from one year to another (see $p$ values in the last column of Table B). For example, $48 \%$ of Catholics in 1996 prefer to have a balance, but that changes to $40 \%$ in 2006 . Their indiffer- ence goes up from 9\% in 1996 to 15\% in 2006 $(\mathrm{p}<0.000)$. On the other hand, for people without religious affiliation, for example, those percentages are not statistically different.

In Table 1, I show desired sex ratios for each socio-demographic group for each separate year. Sex ratios were calculated in the aggregate, dividing the number of desired sons by the numbers of desired daughters in each group and multiplying by one hundred. Women who reported that they were "indifferent" were not counted or were partially counted ${ }^{6}$.The assumption is that, in the absence of preferences, all values would have to be equal to 100 (100 sons for each 100 daughters) and values would have to be the same across sociodemographic groups and across time. Table 1 shows that in Brazil, in general, a slight but pervasive daughter preference is consistently more prevalent than son preference. Notice how most ratios are below 100 , sometimes reaching values as low as 85 . I performed Chi Square tests of the same groups over time (for example, comparing the ratio for black women without children in 1996 with the ratio for black women without children in 2006) and the tests did not show that the proportions are different from one year to another. For example, the ratio for women without children who go to work in 1996 is 99, and that is not statistically different from the ratio of women without children who go to work in 2006: 92.

As explained in the previous section, the dependent variable created using sex preferences is multinomial and contains four categories: Balance - preference for balance, Indifferent - no sex preference, Daughter preference - preference for girls, and Son preference - preference for boys. The categories vary according to family size. As can be noticed in Box 2, women who want only one child do not include the category Balance, so the dependent variable at the multinomial logistic only has three options: Indifferent, Son and Daughter, having 4\%, $5.7 \%$, and $4.1 \%$ of the sample in 1996 and $7.7 \%$, $6.2 \%$, and $3.7 \%$ in 2006 , respectively.

As for women who want three children, notice in Box 2 how bgg and bbg were considered a preference for Balance, instead of a preference for Daughter and Son respectively as some could argue. In fact, 
categories for pure daughter or son preference (ggg, gxx, bbb, bxx) have such small sample sizes (24 cases in 1996 and 19 in 2006) that any multinomial analysis would be unfeasible. So, instead of running a Multinomial Logistic Model for parity of three children, I will use this opportunity to run a Binomial Logistic Regression of Balance compared to Indifference. I opted not to work with women who wish for more than four children, but their compositions are included in the results of Table 2.
It is very important to keep in mind that although pure daughter or son preference is only a small part of the sample regardless of number of children, compositions that contain more girls than boys but are still mixed, such as ggb, are a big part of the sample. So, they could be helping to keep the sex ratios low on Table 1 (because they contribute more girls at the denominator of the sex ratio) at the same time that they increase the preference for balance at the multinomial logistic models because this is where they were classified in Box 2 .

Table 1

Total Desired Sex Ratios, Brazil, 1996 and 2006, WomenWithout Children.

\begin{tabular}{|c|c|c|c|}
\hline & & \multicolumn{2}{|c|}{ Women without children } \\
\hline & & 1996 & 2006 \\
\hline & & DSR & DSR \\
\hline \multicolumn{2}{|l|}{ TOTAL } & 98 & 94 \\
\hline \multirow[t]{2}{*}{ Race } & White & 99 & 95 \\
\hline & Black & 98 & 94 \\
\hline \multirow[t]{3}{*}{ Religion } & Catholic & 98 & 94 \\
\hline & Protestant & 101 & 96 \\
\hline & Non-Religious & 97 & 96 \\
\hline \multirow[t]{2}{*}{ Urbanicity } & Urban & 98 & 94 \\
\hline & Rural & 99 & 95 \\
\hline \multirow[t]{5}{*}{ Region } & North & 97 & 99 \\
\hline & Northeast & 97 & 89 \\
\hline & Southeast & 99 & 96 \\
\hline & South & 105 & 94 \\
\hline & Center-West & 100 & 95 \\
\hline \multirow[t]{5}{*}{ Education Level } & None & 99 & 89 \\
\hline & Elementary & 97 & 93 \\
\hline & Some high school or middle school & 101 & 94 \\
\hline & High school graduates & 100 & 97 \\
\hline & College & 94 & 94 \\
\hline \multirow[t]{5}{*}{ Wealth Index (quintile) } & 1 & 98 & 85 \\
\hline & 2 & 98 & 93 \\
\hline & 3 & 100 & 98 \\
\hline & 4 & 97 & 93 \\
\hline & 5 & 98 & 96 \\
\hline
\end{tabular}


Table 1

Total Desired Sex Ratios, Brazil, 1996 and 2006, Women Without Children.

\begin{tabular}{|c|c|c|c|}
\hline & & \multicolumn{2}{|c|}{ Women without children } \\
\hline & & 1996 & 2006 \\
\hline & & DSR & DSR \\
\hline \multicolumn{2}{|l|}{ TOTAL } & 98 & 94 \\
\hline \multirow[t]{2}{*}{ Church attendance } & No & 96 & 91 \\
\hline & Yes & 99 & 95 \\
\hline \multirow[t]{2}{*}{ Virginity Status } & No & 98 & 96 \\
\hline & Yes & 99 & 93 \\
\hline \multirow[t]{2}{*}{ Work Status } & No & 98 & 96 \\
\hline & Yes & 99 & 92 \\
\hline \multirow[t]{3}{*}{ Marital Status } & Married & 99 & 94 \\
\hline & Separated/Divorced & 96 & 90 \\
\hline & Single & 99 & 95 \\
\hline \multirow[t]{4}{*}{ Age } & $15-19$ & 97 & 95 \\
\hline & $20-29$ & 100 & 94 \\
\hline & $30-39$ & 96 & 99 \\
\hline & $40-49$ & 100 & 85 \\
\hline
\end{tabular}

Note: I performed Pearson Chi2 tests of pairwise comparisons of categories within social-groups (i.e. white, black). None of the tests were significant, which means that the proportion of daughters and sons (the desired sex ratio) doesn't change from one year to another (not shown).

Sources: DHS 1986 (BEMFAM, 1987) and PNDS 2006 (Ministério da Saúde, 2008).

The models can be seen in Table 2 (all desired family sizes), Table 3 (women who want to have one child), Table 4 (women who want two children), and Table C of the Supplemental Material (women who want three children). The results are described in relative risks (RRR), which are comparisons between the response category and its reference category. In Table C, in the Supplemental Material, the results are shown in the odds ratio.

Below, I will analyze the findings in light of the literature review, which requires me to alternate the order in which the Tables and Boxes are brought to the discussion

\section{Marital Status}

Analysis of Table 2 shows how, in general, married women seem to have higher risks of being in- different because, consistently, women of other marital statuses, such as singles and divorcees, show increased risks of preferring balance or any gender over indifference. Take, for example, single women in 1996: they have higher risks (3.18 and 2.7 times greater risks) than married women of preferring daughters and sons compared to indifference, respectively. They also have a $68 \%$ higher risk of preferring balance rather than being indifferent compared to married women. The same thing happens for divorced/separated women, who in 1996 were more than twice as likely as married women to prefer balance rather than being indifferent, and had 3.72 and 4.85 times married women's risks of preferring daughters and sons. In 2006, singles' preference for balance rather than indifference was stronger than that of married women, and the sex preference continued to be salient for divorced/separated women. 


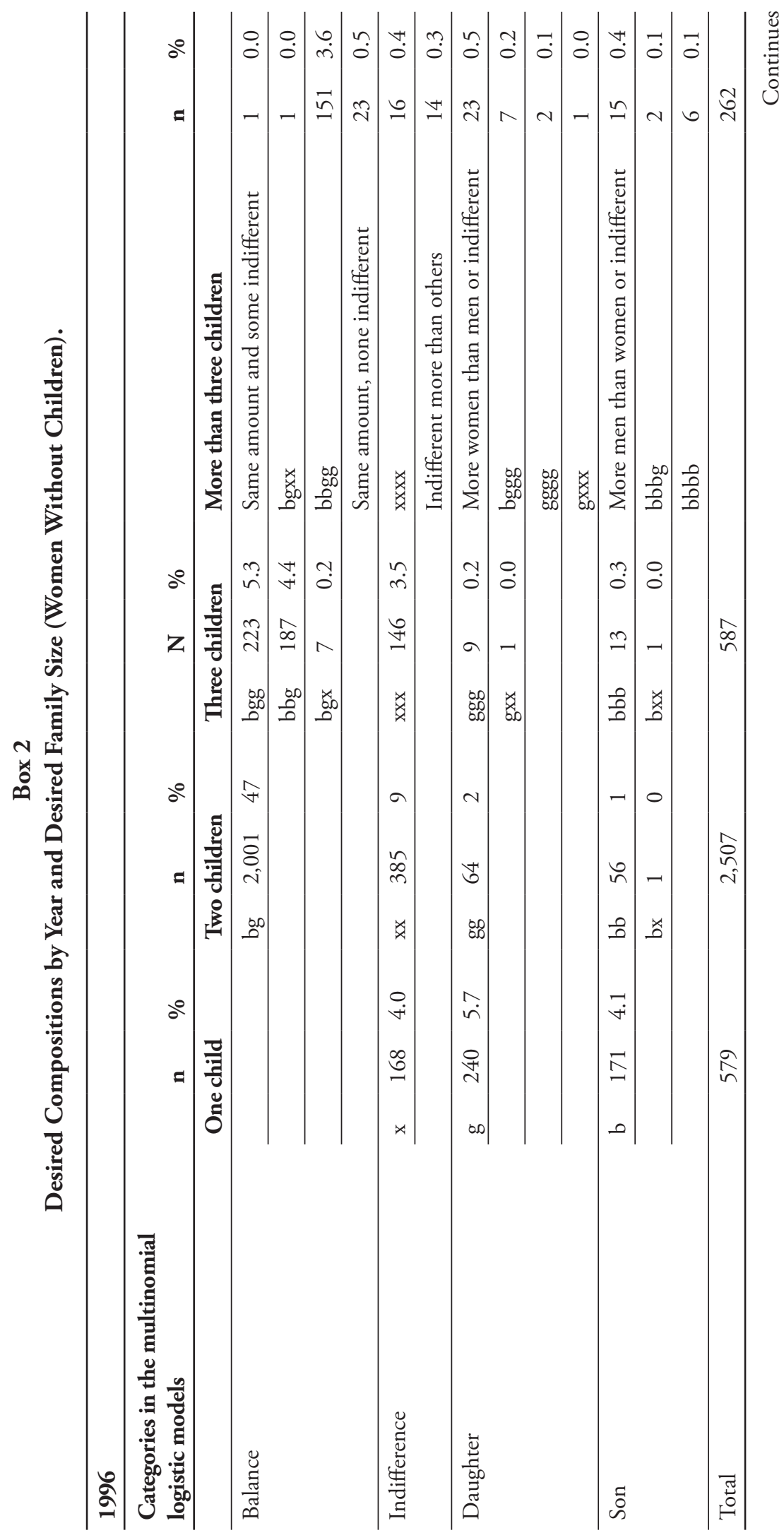




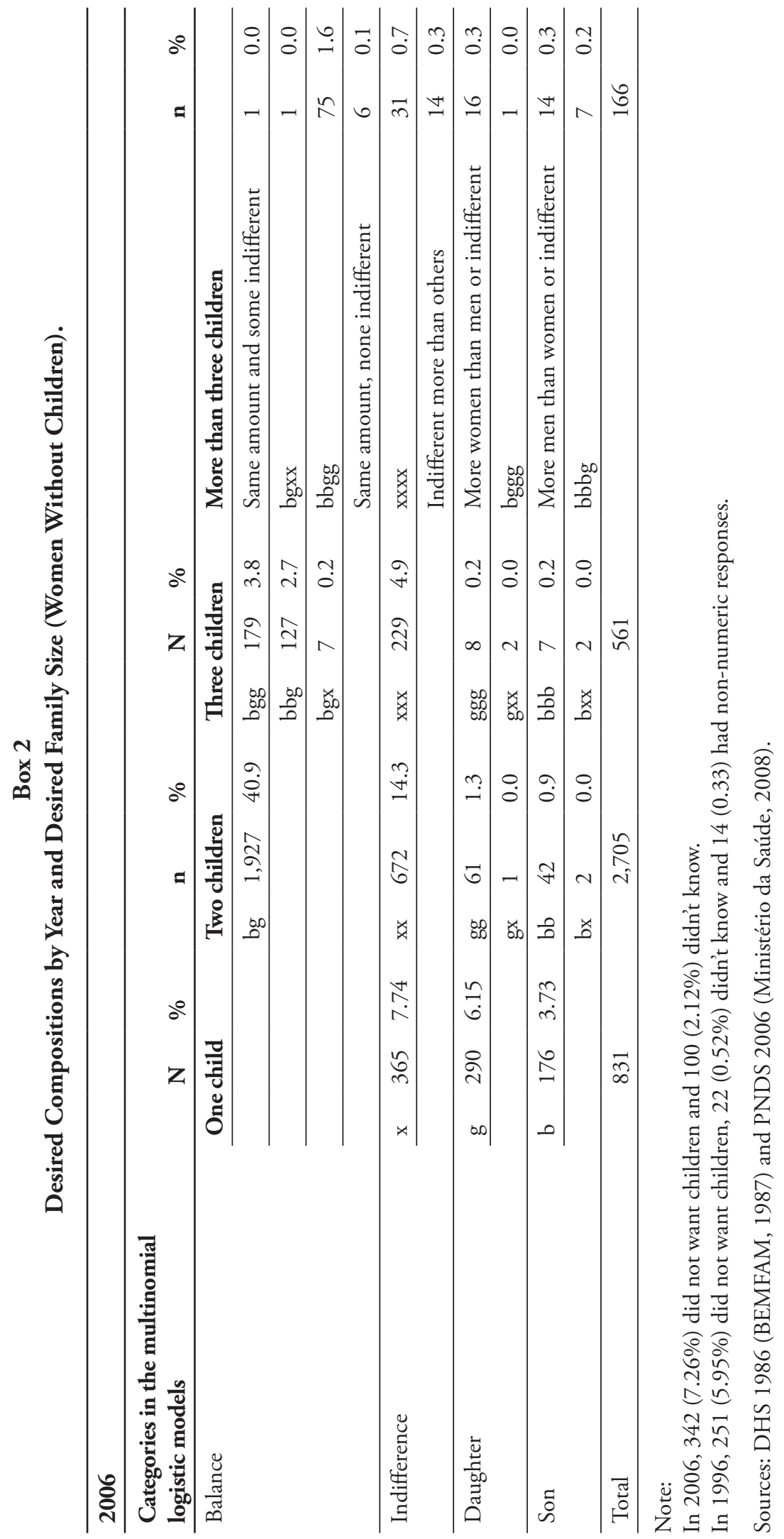




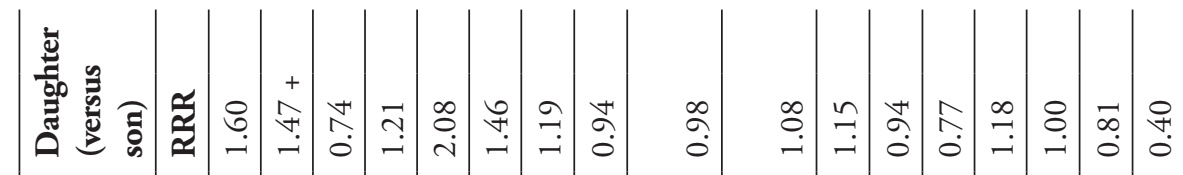
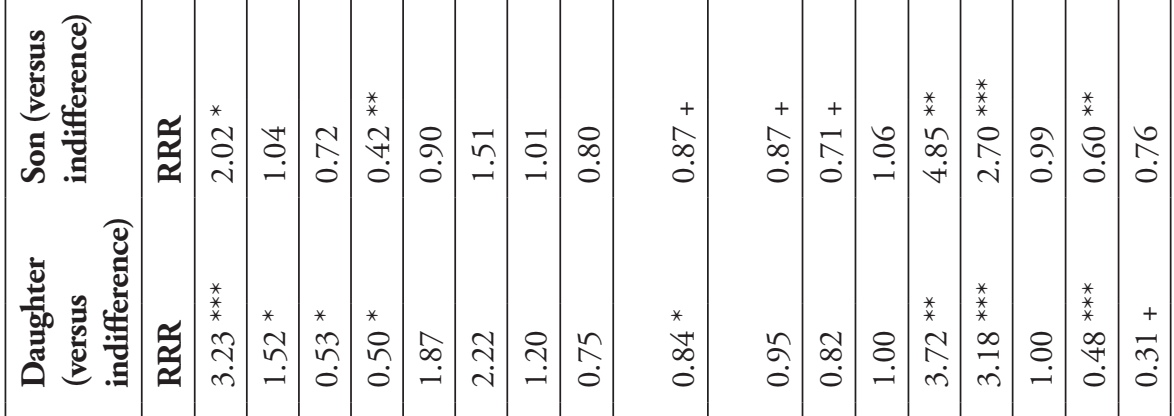

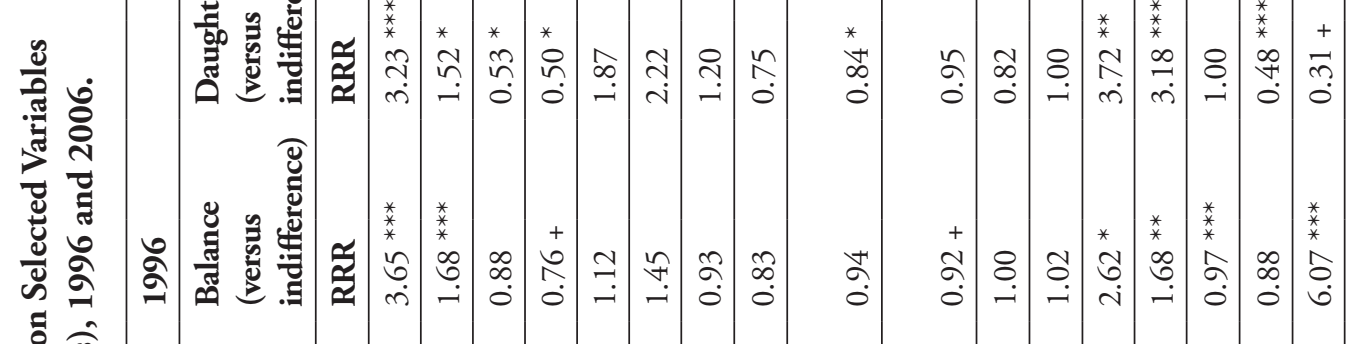

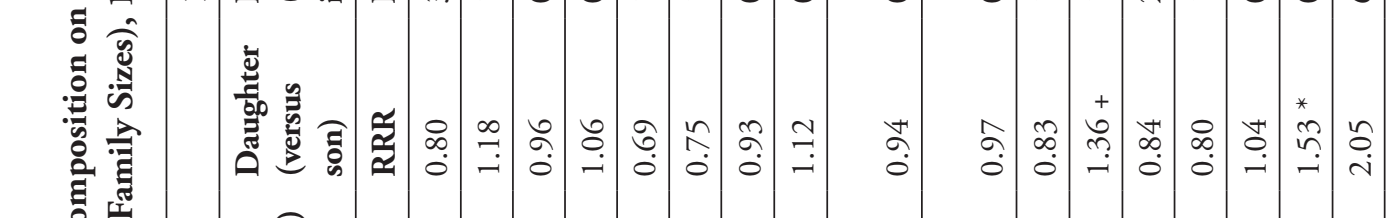

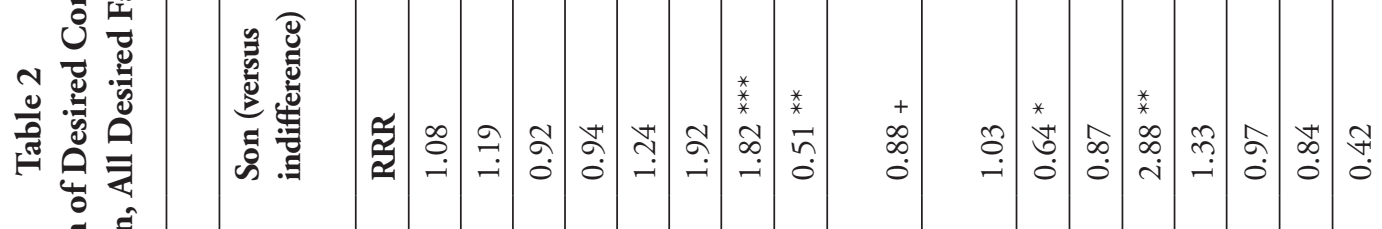

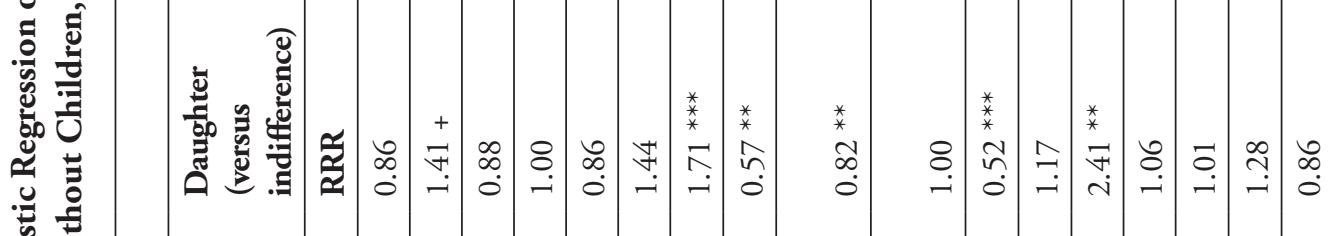

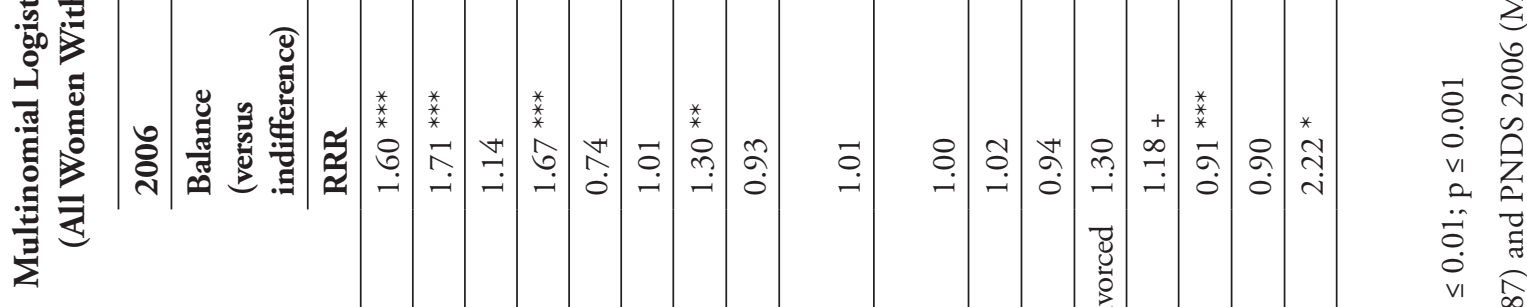

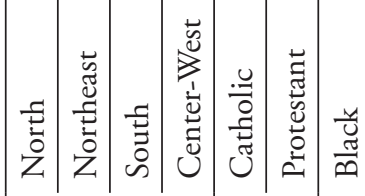

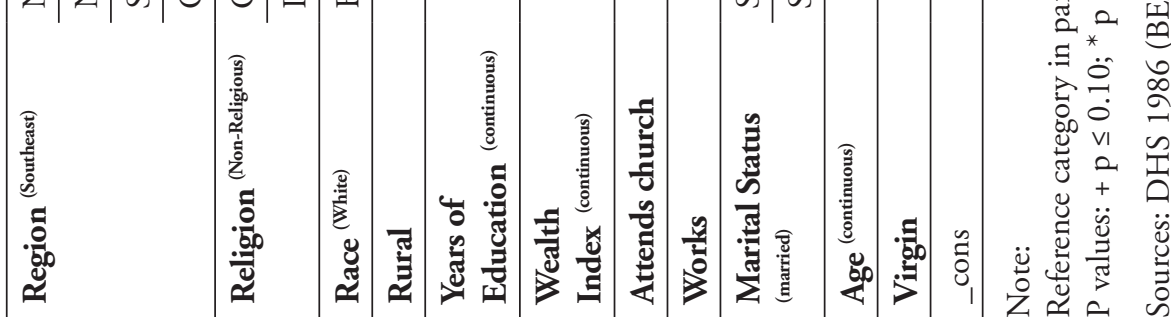



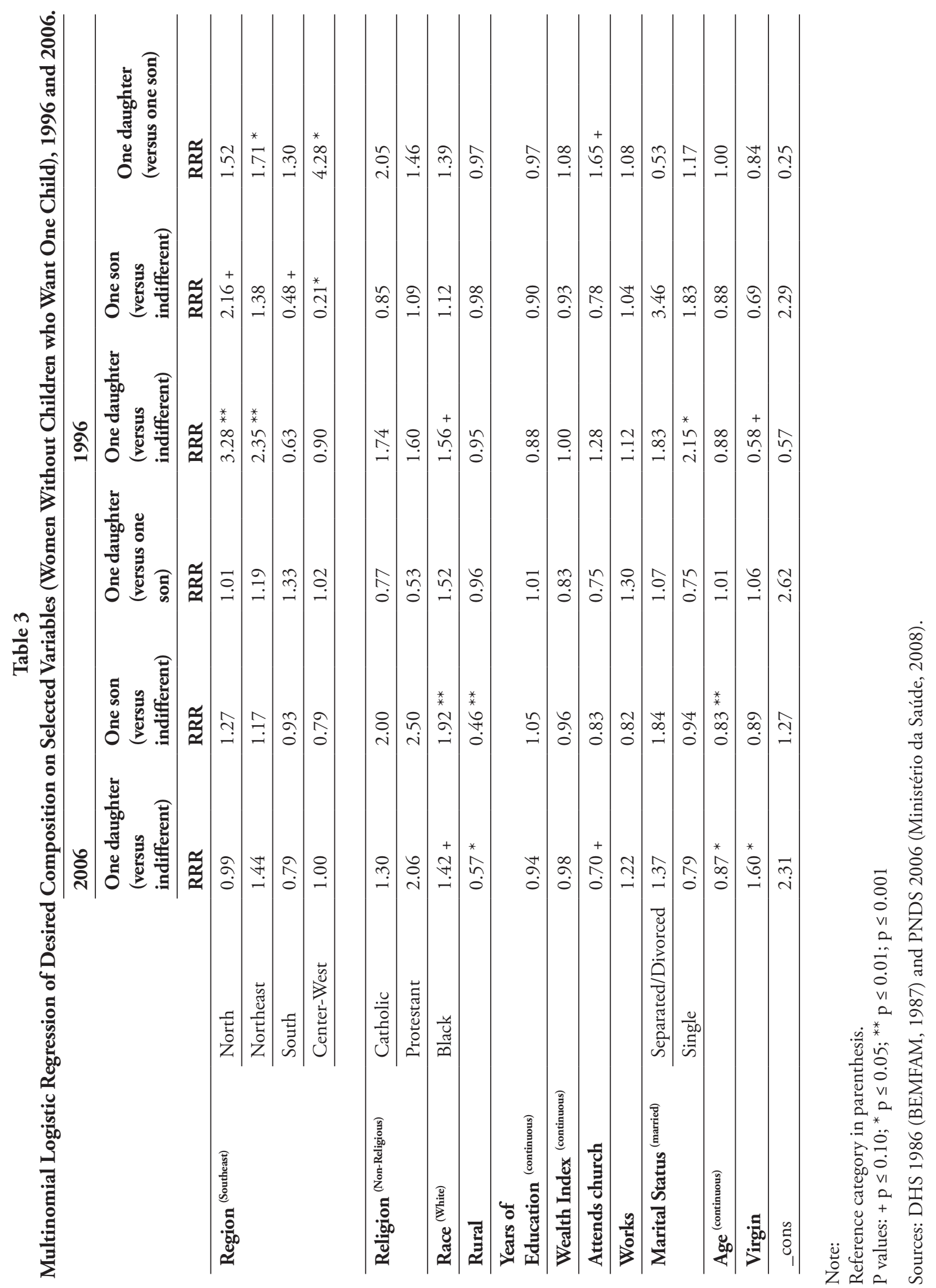


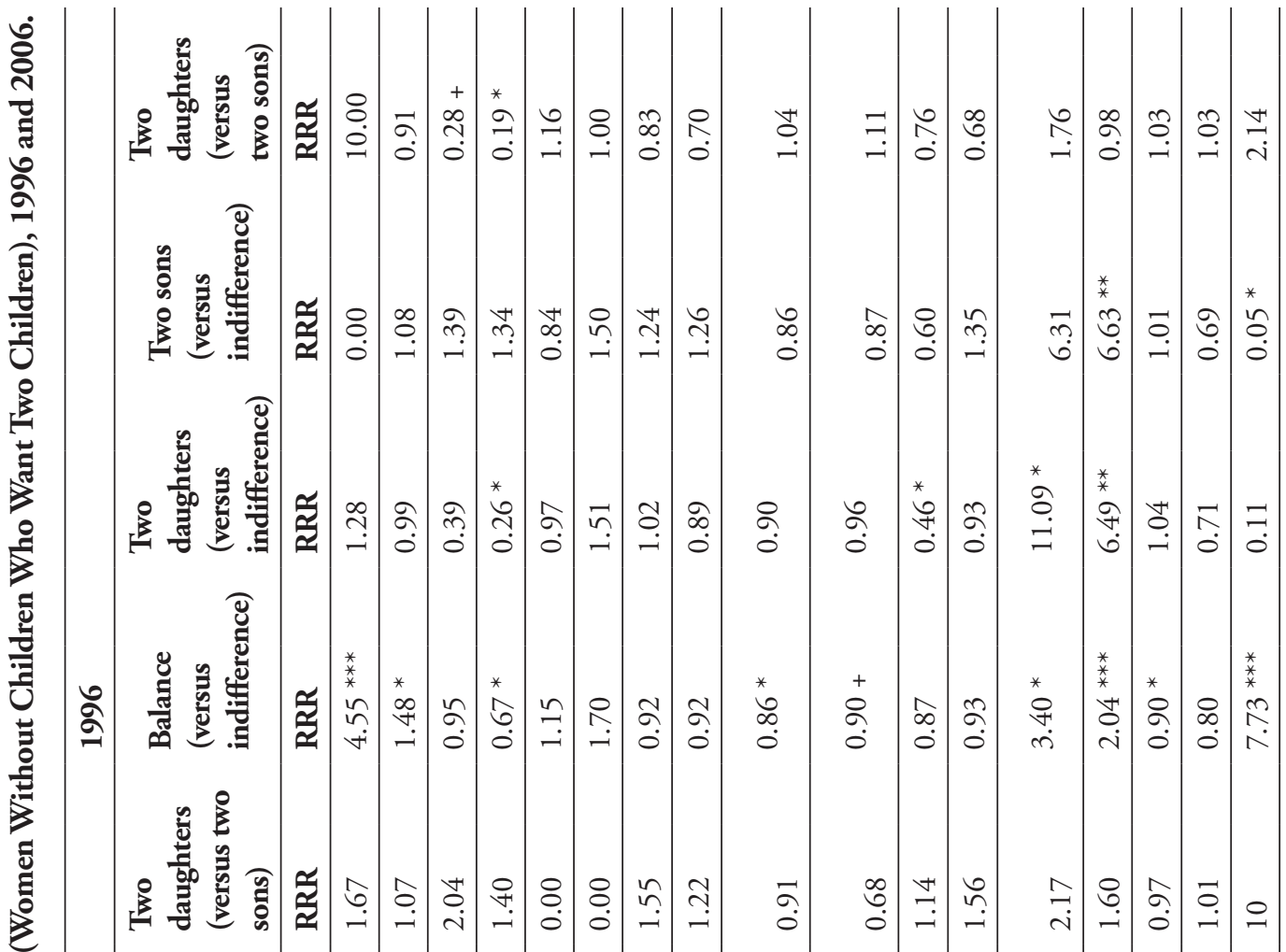

章 $\frac{3}{\frac{0}{2}}$

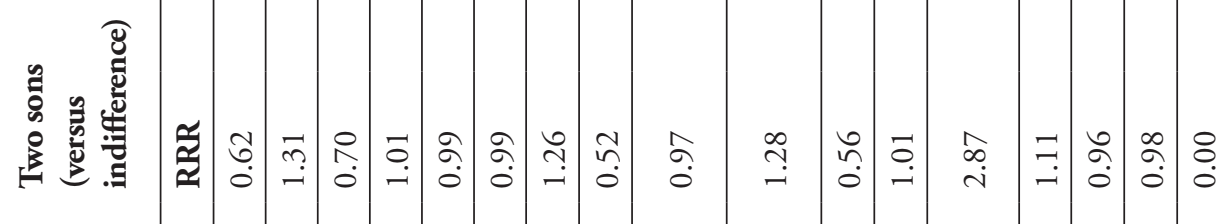

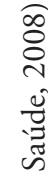

$\frac{2}{\mathscr{N}}$

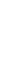

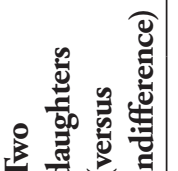

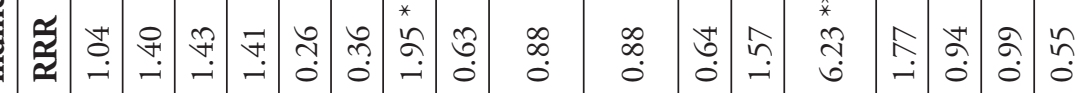

ठํํㄹ

逍

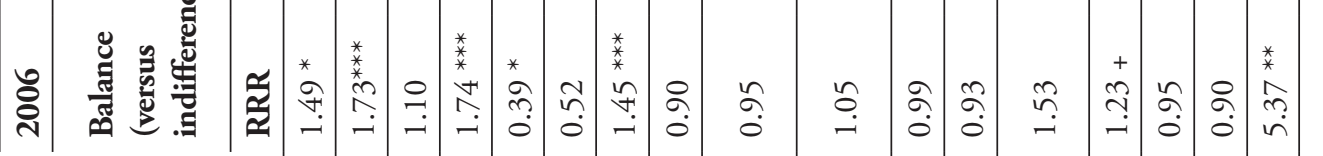

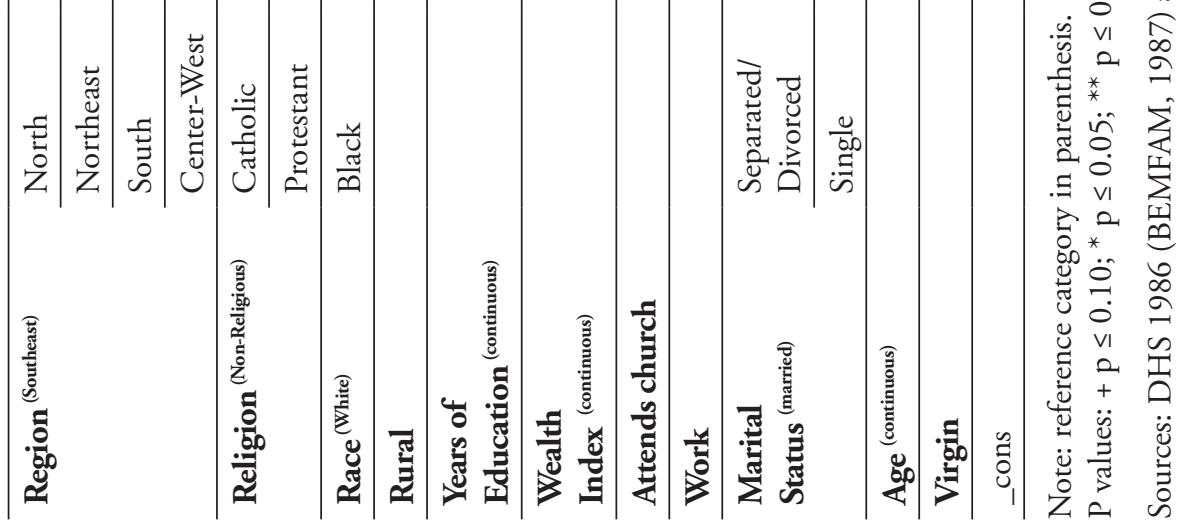


For women who only want one child, as can be seen on Table 3, marital status becomes less important. Singles have higher risks (2.15 times the risks of married women) of preferring a girl over indifference when compared to married.

In Table 4, for women who want two children, the coefficients for marital status mimic those of Table 2 going in the same direction. For women who want even bigger family sizes, however, the relationship reverses, as can be seen in Table C of the Supplemental Material for women who want 3 children: in this table, singles and divorced/separated women have lower odds of wishing a balance compared to married women. When I consider a bgg a girl preference and bbg a boy preference instead of balance, the coefficient for singles' preference for daughters becomes larger and more evident (not shown).

Age

Women's age consistently contributes to an increase in indifference. That means younger women, in general, have more sex preferences. Notice in Table 2 that, with each additional year of age, the relative rate for preferring balance rather than being indifferent is expected to decrease by a factor of 0.91 in 2006 and 0.97 in 1996, keeping the other variables in the model constant. In other words, the older a woman is, the more indifferent she is to the sex of her offspring.

The same tendency is found for women who want only one child (Table 3), or two children (Table 4), but not for those who want three children (Table C in Supplement Material).

\section{Virginity}

Analyzing all family sizes in Table 2, virginity was associated with more indifference in 1996 (the relative risks for virgins relative to non-virgins would be expected to decrease by a factor of 0.48 and 0.60 of preferring daughters or sons over indifference). But in 2006, virgins start to demonstrate more daughter preference compared to sons (1.53 in 2006). For women who only want one child, the same trend is observed on Table 3 . In the same table, the coefficient shifts to 1.6 the risks of non- virgins of being in the daughter preference category when compared to son preference.

\section{Place of residence}

In 1996, coefficients for place of residence are non-significant, which means both rural and urban areas behave the same way in relation to sex preferences when controlled by other covariates.

In 2006, however, in both Table 2 and Table 3, inhabitants of rural areas have lower risks of having any sex preference whatsoever when compared to urban areas. Take, for example, Table 2: for rural women, the relative risks for daughter and son preference would be expected to decrease by half ( 0.57 for daughters and 0.50 for sons) compared to the risks of women in urban areas when the other variables in the model are held constant.

When analyzed together with the Desired Sex Ratios of Table 1 , this means that the sex ratio above 100 that is reported for rural women is probably associated with being indifferent, not with preferring a balance.

\section{Geographic Region}

Although only the South region was contemplated in the hypothesis, the North and Northeast regions consistently appear as having a higher rate of sex preference when compared to the Southeast, a fact that deserves further exploration.

In Table 2, the North and Northeast tend to have more preference for balance than indifference when compared to the Southeast region. The chance of women in the North and Northeast being in the Balance category is $60 \%$ and $70 \%$ higher than the chances of women in the Southeast being in that category in 2006. In 1996, the coefficients are even stronger: the risks of the North reach 3.65 times the risks of the Southeast, and the Northeast has 1.68 times more risk. Both regions also have higher risks of preference for girls over indifference, especially in 1996. In that year, changing the reference category to sons (as can be seen in the last column of Table 2) also reinforced the Northeast's strong preference for daughters: they have $47 \%$ higher risks of preferring daughters over sons than 
the Southeast. The region Center-West also shifts from a behavior of being more indifferent (lower chances of having a sex preference whatsoever in 1996) to having a preference for balance in 2006.

For women who want to have one child (Table 3), the coefficients follow the same trends as in Table 2, but the Center West, in 1996, appears to have more daughter preference relative to son preference (4.28) compared to the Southeast. This preference weakens in 2006. In 1996, the Northeast has $71 \%$ more risks than the Southeast of choosing girls compared to boys.

For women who want to have two children (Table 4), the only novelty is the South's and Center-West's strong son preference. Notice how women in those two states have only $28 \%$ and $19 \%$, respectively, the risks of women in the Southeast of preferring daughters to sons in 1996. Those coefficients are not consistent over time.

These regional preferences can be related to the patterns found in Table 1 in 2006. The South has a much higher sex ratio (more balance or male preference) than the Southeast. The Northeast has a much lower sex ratio (more daughter preference) than the Center-West.

\section{Religion and frequency of religious attendance}

Religion is much less influential in sex preferences than I had previously thought. Because no clear statistically significant tendency is observed, the coefficients won't be commented on in detail.

When it comes to church attendance, however, there is more indication that attendance increases indifference (Table 2, 3 and 4). For family sizes of one child, however, as can be seen on Table 3 , when compared to people who don't go to church, churchgoers have a $65 \%$ higher risk than non-churchgoers of preferring one girl over one boy in 1996.

Race

When looking at all desired family sizes on Tables 2 through 4, blacks, compared to whites, in 2006, demonstrate a strong preference for balance or for each of the sexes individually when com- pared to indifference. That means whites are more indifferent, in general.

Take Table 2, for example. Blacks not only have $30 \%$ higher risks than whites of being in the Balance category (other than indifference), but they also have $71 \%$ and $82 \%$ higher risks than whites of being in the category Daughter or Son.

It seems that in the cases of black women, sex preferences are extremely salient for their reproductive goals, and they are especially inclined toward balance.

\section{Income, Education and Work}

Wealth level, education achievement and work did not seem to matter as much as I had previously thought. On the rare occasions when it was significant, it was in the direction of increasing indifference, as I had expected.

In Table 2, for each additional year of education, the relative risk for daughter or son preference compared to indifference, respectively, would be expected to decrease by a factor of 0.82 and 0.88 in 2006 and 0.84 and 0.87 in 1996. Wealth level behaves in the same way, but with much less significance, although, specifically for women who want three children, wealth slightly increases odds of preferring balance rather than being indifferent (as can be seen on Table C of the Supplemental Material).

Also as expected, in 2006, women who work have a stronger daughter preference when considering all family sizes in Table 2 (36\% higher risks of preferring daughters over sons compared to women who don't work).

\section{Discussion and conclusions}

The dominant preference of Brazilian women is for a balanced sex composition, which is in accordance with the findings of Souza, Rios-Neto and Queiroz (2011). Nevertheless, fewer women in 2006 than in 1996 demonstrate a clear sex preference or even a balance preference; indifference is increasing, in accordance with the findings from Pollard and Morgan (2002). This finding suggests that, in Brazil, women have been increasingly more likely to base their fertility preferences on the num- 
ber of their offspring rather than on desired sex, possibly driven by the decline of fertility. Sticking to a favorite sex composition might mean having more children than planned.

The decline in the search for balance might also mean that, in Brazilian society, gender divisions might be getting less rigid so that daughters and sons have the same value and fulfill their mothers' expectations in the same way. As Pollard and Morgan (2002) state, when the benefits of each gender are different, people might have different motivations to have one or another because sons and daughters are not substitutable. Nevertheless, this paper provides evidence of a pervasive secondary daughter preference, in line with the findings of Miranda, Dahlberg and Andersson (2018). This behavior deserves further consideration in future studies to elucidate whether having a daughter is more versatile than having a son.

As for the specific hypothesis testing the influence of social schemas on fertility intentions and compositions, several hypotheses were confirmed, and several were rejected:

Being single, being separated, and being divorced are associated with a daughter preference or with balance. Being married, on the other hand, contrarily to what I expected, seems to increase indifference regarding gender rather than increasing the desire for balance. The virginity hypothesis is also partially held. Virgins seem to be more indifferent in 1996, but change to a daughter preference in more recent years.

The hypothesis related to the geographic regions is confirmed. The South has consistently more son preference than the Southeast, while the North and (more strongly) the Northeast have daughter preference. Future work should investigate the reasons for this consistent daughter preference in the North and Northeast regions. Reasons could be related to higher levels of female migration to urban areas in the decades prior to both survey years. This mass migration altered the sex ratio in both urban and rural areas and was responsible for a process named "masculinization of the rural areas" in Brazil (Camarano, 1997). So, a preference for daughters could be associated with women's empowerment in this new environment or with their attempt to re- spond to the societal forces that drove them away from rural areas. It could also be related to the fact that, in those areas where the major proportion of work available consists of strenuous manual work, young women have better educational outcomes than their male counterparts. Although the interaction between geographic region, place of residence and education level has not been explored here, this certainly deserves future study.

Nevertheless, women who live in rural areas are more indifferent to their children's sexes when compared to urban women, who prefer sex balance, which is not consistent with the hypothesis.

Contrarily to what I expected, blacks do not have a very high rejection of males. Instead, this social group tends to have very strong preferences for both genders - or for balance. That means that, although the literature gives reasons to believe that black boys are rejected by society, they are not being rejected inside their own households. Future work should try to explore how gender roles in Brazil might vary by race and how rigid this gender system is.

I did not find that patriarchal religious affiliations are an important predictor of child preference, but future studies should look into religious traditions that were not considered in this paper, such as the ones with African heritage that follow matriarchal authority.

As predicted, higher education levels and wealth increase indifference, while work increases daughter preference. It seems that for the lower-class and lesseducated, preferences are in fact more salient.

Future work should shed light on other factors that might play a role in intentions that were not analyzed in this paper due to data availability, such as partner's preference, sibling relationships, low self-esteem, parenting style, etc. Future work should also investigate whether not having a desired composition influences decisions regarding contraceptive use, sterilization, and remarriage in case of divorce.

In conclusion, this paper presents evidence that "gender indifference" has become more pronounced as fertility declines, but the majority of Brazilian women still look for balance or for a daughter "to complete the family." That search is responsible for the effects of sex preferences on fer- 
tility. It is also important to say that it has been 10 years since the last PNDS. It is very possible that such patterns have been somewhat transformed in the face of the most recent fertility decline and the increases in the average level of education.

\section{Notes}

1 The description of these two different realities elucidates the necessity of increasing female empowerment and autonomy to promote gender equality (for complete review, see Guilmoto, 2012). Although financial incentives are interesting because they can counterbalance the expected returns in investing in sons, literature considers that among all attempts to increase gender equality, the most successful are those that aim at a change of attitudes, such as allowing women to complete education, to have a valuable income, to exercise political influence, and to have more freedom. In India, urbanization also changed women's status because it reduced the centrality of sons in their parents' lives. Industrialization also reduced the importance of family because people can live independent of their families based solely on their skills and qualifications. Female education and employment gave women greater ability to function and contribute to their parental households (Das Gupta et al., 2002). Even radio and television have their role in boosting female autonomy and independence (Jensen and Oster, 2008).

2 For more information on Desired Family Size, see Coutinho and Golgher, 2018. These rates slightly differ from the ones published in Bemfam (1987) and in PNDS 2006 (Ministério da Saúde, 2008) because they refer to the 36 months prior to the surveys and because, in order to calculate discrepancies between Total Fertility Rates and Desired Family Size, it was necessary to delete from the sample women who did not provide numerical answers to the questions about Ideal Family Sizes (i.g. provided answers such as "Up to God", "Doesn't know," or "Did not answer.").

3 Data from the PNDS 2006 show that almost half of pregnancies in Brazil were unplanned (Ministério da Saúde, 2008). The proportion is higher for women of low socioeconomic status and of low education level. Among the possible reasons for that inequality are their lack of access to contraceptive methods, method failure or inconsistent use, and gender inequality (through low power of negotiation) (Ministério da
Saúde, 2008; Wong, 2009; Casterline \& Mendoza, 2010; Lacerda et al., 2005). Other reasons are early onset of sexual intercourses (Cavenaghi \& Rodríguez, 2014) and restrictive abortion laws (Le et al., 2014).

4 Explanations of the construction of the Wealth Index can be made available upon request.

5 I did, however, perform the regressions just for young women. The results are similar given the fact that $75 \%$ of the women without children are below 25 years old. While the mean age of the sample is 30.8 in 2006 and 29.7 in 1996 , for the women without children, this number falls to 22.8 in 2006 and 21.9 in 1996.

6 For example, women who desire three children, one girl and two children whose sex is not specified, would contribute 1 female to the calculation, and nothing else.

7 I have run the analysis using multiple options of categories and references and the results do not change significantly. So the most parsimonious model was chosen to be represented.

\section{CITED REFERENCES}

ABRAMOVAY, R.; CAMARANO, A. A. (1998). Êxodo rural, envelhecimento e masculinizaçâo no Brasil: panorama dos últimos cinquenta anos. Revista Brasileira de Estudos de População, 15(2), 45-65.

ARNOLD, F. (1997), "Gender Preferences for Children". Demographic and Health Surveys Comparative Studies No.23. 1997.

BERQUO, Elza, GARCIA, Sandra, \& LIMA, Liliam. (2012). "Reprodução na juventude: perfis sócio demográficos, comportamentais e reprodutivos na PNDS 2006". Revista de Saúde Pública, 46(4), 685-693. Epub July 10, 2012. Retrieved November 13, 2015, from http://www.scielo.br/scielo.php?script=sci arttext\&pid=S0034-89102012000400013\&ln $\mathrm{g}=\mathrm{en} \& \mathrm{t} \operatorname{lng}=\mathrm{pt}$.

BEMFAM. (1987), Sociedade Civil Bem-Estar Familiar no Brasil. DHS Final Reports. Brazil DHS, 1986. Rio de Janeiro, Brasil and Macro International Inc. Columbia, Maryland, USA. December

BLAU, F. and KAHN, L. (2000) "Gender differences in pay”. NBER working paper, n. 7732. 
BONGAARTS, J. (2013), "The Implementation of Preferences for Male Offspring". Population and Development Review, 39: 185-208. doi: 10.1111/j.1728-4457.2013.00588.x

BROCKMANN H. (1999), "Girls preferred ? Changing patterns of sex preferences in the two German states", Working Paper. MaxPlanck Institute for Demographic Research. 1999-010, September

CASTERLINE, J.B.; MENDOZA, J.A. (2010), "Unwanted fertility in Latin America: historical trends, recent patterns." Pp. 193-218 in S. Cavenaghi (Ed.) Demographic Transformations and Inequalities in Latin America: Historical Trends and Recent Patterns, Serie Investigaciones 8, Rio de Janeiro: ALAP.

CAVENAGHI, S., RODRIGUEZ, J. (2014), Adolescent and youth fertility and social inequality in Latin America and the Caribbean: what role has education played?, GENUS, LXX:1, 1-25

CARVALHO, Angelita Alves. (2014), Insatisfação ou discrepância? Uma análise das preferências de fecundidade e do comportamento reprodutivo de casais de alta escolaridade em Belo Horizonte/MG (Tese de mestrado) Universidade Federal de Minas Gerais, UFMG, Brasil. CEDEPLAR/UFMG.

CONSELHO NACIONAL DE JUSTIÇA (2015). Cadastro Nacional de Adoção. Relatórios Estatísticos. Website. http://www.cnj.jus.br/programas-e-acoes/cadastro-nacional-de-adocaocna. Last access: 11-11-2015.

COUTINHO, R. Z. (2016) The Transition to Low Fertility in Brazil. (Tese de Doutorado). Departamento de Sociologia. University of North Carolina at Chapel Hill. Estados Unidos.

COUTINHO, R; GOLGHER, A. (2018), "Modelando os determinantes próximos da fecundidade para o Brasil". Revista Brasileira de Estudos de População, v.35, n.1.

DAS GUPTA, M.; MARI BHAT, P.N. (1997) "Fertility decline and increased manifestation of sex bias in India”. Population Studies 51(3): 307-316

DAS GUPTA, Monica et al. (2002). "Why is son preference so persistent in East and South Asia? A cross-country study of China, India and the Republic of Korea," Policy Research Working Paper. The World Bank.
DYSON, Tim, and MOORE, Mick. 1983. "On Kinship Structure, Female Autonomy, and Demographic Behavior in India”. Population and Development Review 9 (1). Population Council: 35-60. doi:10.2307/1972894.

GONCALVES, Lucia Takase Hisako et al. (2013), "Convívio e cuidado familiar na quarta idade: qualidade de vida de idosos e seus cuidadores". Revista brasileira de geriatria e gerontologia. [online]. Vol.16, n.2

GUILMOTO, Christophe Z. 2012. Gender Imbalances at Birth. Trends, Differentials and Policy Implications. Bangkok: UNFPA.

HANK K., H.-P. KOHLER. 2000, "Gender preferences for children in Europe: empirical results from 17 FFS countries," Demographic Research [Online] 2, available at http:// www. demographic-research. org/Volumes/Vol2/ 1

HANK, K. H-P. KOHLER. (2003) “ Les préférences relatives au sexe des enfants : de nouvelles données allemandes ," Population, 1 (Vol. 58) , p. 139-150 URL : www.cairn.info/ revue-population-2003-1-page-139.htm. DOI : 10.3917/popu.301.0139.

JACOBSEN R., Møller, H., Engholm, G. (1999), "Fertility rates in Denmark in relation to the sexes of preceding children in the family". $\mathrm{Hu}$ man Reproduction, 14, pp. 1127-1130.

JUHN, C.; Potter, S. (2006) "Changes in Labor Force Participation in the United States". Journal of Economic Perspectives, Volume 20, Number 3-Summer, pages 27-46.

LACERDA, A. M. et al. (2005). "Mensuração e perfis de demanda insatisfeita por contracepção nos municípios de Belo Horizonte e Recife, 2002". Revista Brasileira de Estudos da População, [S.1.], v. 22, n. 1, p. 113-129, jan./jun.

LAMEIRAO, Adriana Paz. (2011). Mercado de Trabalho, Desigualdade Social e de Gênero. Seminário Nacional da Pós-Graduação em Ciências Sociais da UFES. v1 n1

LE, H. H.; CONNOLLY, M. P., BAHAMONDES, L., CECATTI, J. G., YU, J.; HU, H. X. (2014). "The burden of unintended pregnancies in Brazil: a social and public health system cost analysis". International Journal of Women's Health, 6, 663670. https://doi.org/10.2147/IJWH.S61543 
MARLEAU, J.,MAHEU, M. (1998) "Un garcon ou une fille? Le choix des femmes et des hommes à l'égard d'un seul enfant." Population. 1998, 53: 1033-1042.

MINISTERIO DA SAUDE. 2008. Pesquisa Nacional de Demografia e Saúde da Mulher e da Criança PNDS 2006, Relatório Final. BRASÍLIA/ DF: CENTRO BRASILEIRO DE ANÁLISE E PLANEJAMENTO. Disponível em: http:// bvsms.saude.gov.br/bvs/pnds/img/relatorio_final_pnds2006.pdf

MIRANDA, V.; DAHLBERG, J.; ANDERSSON, G. (2018). "Parents' Preferences for Sex of Children in Sweden: Attitudes and Outcomes". Population research and policy review, 37(3), 443-459.

MOTTA, A. B. (2010) "A família multigeracional e seus personagens". Educação \& Sociedade, Campinas, v. 31, n. 111, p. 435-458, abr./jun. PARK, Chai Bin, CHO, Nam-Hoon. (1995). "Consequences of Son Preference in a Lowfertility Society: Imbalance of the Sex Ratio at Birth in Korea." Population and Development Review 21 (1). Population Council: 59-84. doi:10.2307/2137413

PAULILO, Maria Ignez S. "O Peso do Trabalho Leve". Departamento de Ciências Sociais- UFSC Revista Ciência Hoje- nº 28/1987.

SILVESTRO, M. L.; ABRAMOVAY, R.; MELLO, M. A. de; DORIGON, C.; BALDISSERA, I. T. Os impasses sociais da sucessão hereditária na agricultura familiar. Florianópolis: Epagri; Brasília, DF: Nead/Ministério do Desenvolvimento Agrário, 2001.

SOUZA, L. R. de; RIOS-NETO, E. L. G.; QUEIROZ, B. L. (2011), "A relação entre parturição e trabalho feminino no Brasil". Revista Brasileira de Estudos de População, v. 28, n. 1, p. 57-79, jun.

STEIN, P.; WILLEN, S.; PAVETIC, M. (2014). "Couples' fertility decision-making". Demographic Research, 30, 1697-1731. Retrieved from http://search.proquest.com/docview/155 6066787? accountid $=14244$

TEICHMAN, Y.; RABINOVITZ, D.; RABINOVITZ, Y. (1992), "Gender preferences of pregnant women and emotional reaction to infor- mation regarding fetal gender and postpartum: an examination of Freud's view about motivation and motherhood". Sex Roles. 26: 175-195. WAISELFISZ, Julio Jacobo. (2013) Mapa da Violência 2013. Homicídios e Juventude no Brasil. Juventude Viva, Brasilia.

WAJNMAN, S; RIOS-NETO, E. L. G. (2000), "Quantas serão as mulheres: cenários para a atividade feminina" in ROCHA, M. I. B. (Org.) Trabalho e gênero: mudanças, permanências e desafios. Campinas: ABEP, NEPO/Unicamp e Cadeplar/UFMG; São Paulo: 34.

WALLER, H. (1975), "Sex of children and ultimate family size by time and class". Social Biology. 23: 210-225.

WHINTER, J.; GOLGHER, A. B. (2010), “Uma investigação sobre a aplicação de bônus adicional como política de ação afirmativa na Universidade Federal de Minas Gerais (UFMG)". Revista Brasileira de Estudos de População (Impresso), v. 28, p. 333-360.

WOOD, C., BEAN, F. (1977), "Offspring Gender and Family Size: Implications from a Comparison of Mexican Americans and Anglo Americans". Journal of Marriage and the Family. 39: 129-139.

WORLD ECONOMIC FORUM, 2018. Global Gender Gap Report 2018. Insight Report. Cologny/Geneva Switzerland. ISBN-13: 978-2940631-00-1. Available at: http://www3.weforum.org/docs/WEF_GGGR_2018.pdf. Last accessed 14 Feb 2019. 